Booker, A. (2017). Contingent authority and youth influence: When youth councils can wield influence in public institutions. Revista de Investigación Educativa, 35(2), 537-562

DOI: http://dx.doi.org/10.6018/rie.35.2.274841

\title{
Contingent authority and youth influence: When youth councils can wield influence in public institutions
}

\author{
Autoridad contingente e influencia juvenil: Cuando los consejos \\ juveniles pueden ejercer influencia en las instituciones públicas
}

\author{
Angela Booker \\ University of California, San Diego
}

\begin{abstract}
Studies of youth public participation have dealt with varied conceptions of citizenship that emerge from literatures on human rights, civic engagement, youth development, and youth organizing and activism. Where those conceptions rely on developmental logics that limit or exclude youth participation, young people's attempts to gain authority reveal concurrent ways they navigate these multiple conceptions of participation. Drawing on an 18-month ethnographic study, the analysis presented here focuses on a specific venue for youth participation: a student advisory board. Data includes participant observation, interviews, and artifacts including resolutions and emails. Twenty-one of 27 students, representing roughly 15 high schools in their school district, participated in the study. When students attended to paperwork like bylaws and the state education code, they gained access to contingent authority, a limited but influential form of Weberian authority. Key implications of the study indicate that while youth advisory councils can reliably produce exclusion on developmental grounds, they can also provide the parameters for establishing contingent authority. Paperwork is a key to accessing this form of bureaucratic authority, but exercising it requires sustained, public practice. This article contributes to literatures on youth studies, public participation and more broadly to sociology of education.

Keywords: contingent authority; youth voice; youth councils; political participation; bureaucracy.

Correspondencia: Angela Booker, a1booker@ucsd.edu, UC San Diego, Dept. of Communication \#0503, 9500 Gilman Drive, La Jolla, CA 92093.
\end{abstract}




\section{Resumen}

Los estudios sobre la participación pública de los jóvenes han abordado concepciones variadas de ciudadanía que surgen de las literaturas sobre derechos humanos, compromiso cívico, desarrollo de la juventud y organización y activismo juvenil. Cuando esas concepciones se basan en lógicas de desarrollo que limitan o excluyen la participación de los jóvenes, los intentos de los jóvenes de obtener autoridad revelan maneras concurrentes de navegar por estas múltiples concepciones de participación. A partir de un estudio etnográfico de 18 meses, el análisis presentado aquí se centra en un lugar específico para la participación de los jóvenes: un consejo asesor estudiantil. Los datos incluyen observación participante, entrevistas y artefactos incluyendo resoluciones y correos electrónicos. Veintiuno de 27 estudiantes, que representan aproximadamente 15 escuelas secundarias en su distrito escolar, participaron en el estudio. Cuando los estudiantes asistieron al papeleo como los estatutos y el código de educación del estado, consiguieron el acceso a la autoridad contingente, una forma limitada pero influyente de la autoridad de Weber. Las implicaciones claves del estudio indican que mientras que los consejos consultivos de la juventud pueden producir confiablemente la exclusión en bases de desarrollo, pueden también proporcionar los parámetros para establecer la autoridad contingente. El papeleo es una clave para acceder a esta forma de autoridad burocrática, pero su ejercicio requiere una práctica pública sostenida. Este artículo contribuye a la literatura sobre estudios juveniles, participación pública y, más ampliamente, sobre sociología de la educación.

Palabras clave: autoridad contingente; voz juvenil; consejos juveniles; participación política; burocracia.

\section{Introduction}

In western democracies, youth typically do not hold a concentration of political or economic power and face an uphill climb to participate in and shape public life. They are restricted by age and presumed lack of "readiness" for meaningful participation and often tokenized through modern forms of stratification that permeate social life. Given these conditions, this paper addresses the following questions: how can young people establish authority in processes of public decision-making? Specifically, what does youth civic practice look like, and what are some implications for civic engagement and political participation?

What follows is a discussion of contingent authority, a form of authority that youth may effectively claim and wield in public institutions. The source of this potential power is in the paperwork, and wielding it in ways that establish and sustain authority requires applying technical practice-with purpose and in public-over time. Youth can gain influence in spaces that organize their day-to-day lives (and are governed by powerful adults) through what Weber (1978, p.956) described as "modern officialdom" - the rules governing how official duties are "distributed in a stable way". This stable distribution of authority cradles possibilities and limits young people face in establishing participation rights in processes of public governance. The possibilities emerge through processes of democratization that can build influence. However, that influence will always encounter limitations that render its use complex: 
"The demos itself, in the sense of a shapeless mass, never 'governs' larger associations, but rather is governed. What changes is only the way which the executive leaders are selected and the measure of influence which the demos, or better, which social circles from its midst are able to exert ..." (Weber, 1978, p. 985).

Weber's description here effectively frames the conditions - limits to and flows of interaction between various organized publics and administrative officials - within which young people have frequently sought to amplify their voices in public policy processes. The limits are critical to understanding the routinized power of a large bureaucracy, and in turn, what Mukerji (2011) further described as "contingent, jurisdictional authority". In her analysis of $17^{\text {th }}$ century state administration in France, Mukerji described how people without rank came to wield this contingent authority without disrupting the legitimacy of the government through the use of paperwork. She states, "lower-status state agents [exercised] highly circumscribed and supervised powers, and [were subjugated] on paper to the supervision of men of rank....Still, the new agents ... used their material competencies," to effect political and social change (Mukerji, 2011, pp. 225-226). The paperwork sufficiently limited scope of practice for new, technical officials, ushering their access into traditional domains of power. Contingent authority, then, was carefully limited in scope yet capable of yielding unanticipated effects. The conditions of constraint, when wedded with specific forms of authority, opened a space of influence.

In this paper, I consider how previously excluded youth gained contingent authority in a student advisory board (SAB), a form of youth council established as an official representative body and enacted through the mechanisms of public policy making. Such councils have become relatively common features in modern liberal democracies (Bessant, 2004). The SAB in this case had been formed in the 1960s by the school board - a body of locally elected policy makers for the school district and the district's superintendent. The SAB was a board of student advisors who had been elected or appointed to their positions by the students of each school in the district, and their role was to advise the school board on students' perspectives on policy issues. Results presented here show how the SAB came to understand its paperwork, the written rules that defined the group's role and obligations, through attempts to wield its tools for negotiating meaning and exercising authority in local public policy discourse. In discourses of power, childhood and adolescence frequently signify vulnerability, dependency, pliability, and deficiency, even as there is anticipation of an emergent reliable adulthood. Young people who violate these expectations are often understood to be precocious or delinquent. In either case, their ability to wield authority has been questioned in many, if not most, quarters of civil society.

The paper's contribution is to refine the conventional understanding of bureaucratic power as constraining by offering a situated analysis of youth participation, particularly, young people's access to contingent authority through paperwork. In the next section, I review scholarship that clarifies and critiques frameworks for youth participation. I consider evidence of a paradox that promises young people access to democratic participation while simultaneously reinforcing the state's authority. I then 
evaluate the limitations and possibilities for participation through an advisory board model. Following methodology, I present my analysis of the necessary integration of an awareness of paperwork with practices for wielding contingent authority. I end with a discussion of what is required for youth to acquire this form of bureaucratic authority.

\section{Statement of relevant literatura}

Various approaches to framing youth participation have been used to assert rights to public participation. These include critiques of state-based programs for youth participation (human rights literature), work on youth public participation focused on skills and conditions for effective transitions into societal participation (youth development literature), types of participation and access to them (civic engagement literature), and what youth learn and contribute when exercising agency in local contexts (youth organizing and activism literature).

\section{Youth Access to Public Participation}

Throughout the Western world, young people's participation in liberal democratic societies has been a contested topic (Bessant 2004; Hart, 1992; Matthews, Limb, \& Taylor, 1998; Smith, Lister, Middleton, \& Cox, 2005; Taft \& Gordon, 2013). Scholars and practitioners have analyzed the logics underlying various forms of youth participation, types of experiences and their accessibility, and the degree to which they yield influence or change in varied contexts. The 1989 U. N. Convention on the Rights of the Child established conditions for nations to endorse young people's participation. Yet resulting efforts have been critiqued for promoting tokenism and non-participation while claiming to advance youth influence (Bessant, 2004; Fleming, 2013; Hart, 1992).

Adults with greater authority to organize public forms of participation persistently foster non-participation as a norm for young people, where small numbers of young people may be present but without directing meaningful influence (Taft \& Gordon, 2013). Here, tokenism is of particular concern because of its persistence in organizations like youth councils. Hart (1992) distinguished forms of participation from non-participation by the degree to which youth have a transparent understanding of the relevant issues as well as the choice to become involved in meaningful ways. From a legal standpoint, adults predominantly hold the right of decision-making in Western societies (Veerman, 1992, p. 17). Still, the focus on decision-making in a community context situates authority in what must become a multigenerational space for participation (Camino \& Zeldin, 2002)1. Thus, young people quickly learn participation is likely a charade, making suspect any future opportunities to participate (Matthews \& Limb, 2003).

A more socially constructive perspective, drawn from young people's commentary on their own participation and citizenship suggests that youth participation is an influential factor in societal politics but is difficult to recognize within frameworks that define citizenship by civic duty, achievement of economic independence, or age. When citizenship is framed as socially constructive (Smith et al., 2005) or self-actualizing (Bennett, 2008), young people tend to articulate a sense of participation and influence in the development of community that is fluid and also accessible. With this in mind, 
Fleming (2013) distinguished hard goals - setting up the means for participation - from soft goals-establishing shared values and supporting skilled practice-acknowledging more progress on hard than soft goals. She usefully highlights the ways non-participation persists, while taking seriously young people's reports of positive experiences about their access to participation. However, where influence is limited-particularly in the public policy realm-young people reported being ignored, dealing with adult control, and the tyranny of delay. While this cycle of attention to youth participation can be relied upon to reproduce exclusion, spaces for public participation appear to have increased.

Schooling and the Paradox of Youth Public Participation. Public schools are important spaces for realizing the potential of democratic public participation and where youth have a clear collective claim to citizenship. Yet, this circumstance presents a paradox: the state's largest youth-serving public institution is charged with laying a foundation for democratic participation while also reproducing state authority. Rancière (2010) argued a paradox of democracy emerges as democratic practice requires the persistent undoing of the authority on which the promised stability of a democracy rests. Likewise, as youth claim authority in schools, they undo developmental logics that mandate their presence in the institution. As such, their participation becomes a threat, weakening the will to prepare them for public participation.

Evidence of this split emerges between civic and political opportunities in schools and those in communities. Research on public schools-based civic education in the U.S. raises cautions about a decline of investment in pedagogical support for civics education, threatening both quality and accessibility of opportunity to build civic skills for effective long-term participation in a democratic society (Kahne \& Middaugh, 2008). Likewise, an equally persistent trend of low-proficiency held constant at $24 \%$ for high school seniors in reports posted in 1998 and 2006 (National Center for Education Statistics [NCES], 2011). On the flip side, studies of community-based organizing and activism continue to return strong results for supporting young people's expanded capacity for civic and democratic participation (Ginwright, Noguera, \& Cammarota, 2006). These results are promising albeit with important limitations. They tend to serve smaller numbers of young people than schools can reach, and the mechanism for participation can dissolve after key goals have been achieved. Given these results, scholars and practitioners ask how community and school activism can be translated into forms of democratic participation typically reserved for adults or sequestered from school contexts (Ginwright, et al., 2006; Kirshner, 2015; Soep 2014). Youth advisory councils sit at the crux of this paradox, where they have been positioned to instantiate meaningful participation for youth and yet remain structurally limited.

Limits to Authority. Taft and Gordon (2013) provided a general description of what youth councils share in common: connection with policy makers, formal and official role in governance, availability of staff and training, and a size of between 15 and 25 high school aged students. These councils have been celebrated as an advance in producing participatory spaces for young people (Matthews et al. 1998; Smith et al., 2005) and critiqued for their undemocratic and non-participatory enactments (Matthews and Limb 2003; Westheimer \& Kahne, 2004). 
Taft and Gordon (2013) addressed young people's critiques of their experiences on youth councils as normative and nondemocratic and set those experiences in contrast with alternative models of democracy employed by youth movements. The young people in their studies had notably abandoned the youth council model after direct experience with the "political marginality" they frequently engender.

While the school district SAB is susceptible to these established critiques, what is distinct in this case is the emergence of a form of authority available to young people within the parameters defined by the state. It may be tempting to read this as a positive point in the ledger for youth councils. I caution, however, that where contingent authority becomes an accessible tool young people can wield, it also remains meaningfully limited within broader state power. In other words, it is hopeful about its shift in participatory access but realistic about the frightening resilience and stability of a bureaucracy, which Weber (1978) noted is likely to persist even in the face of revolution (p. 987).

\section{Data and methods}

The following research question guided the initial data collection for this study: What does youth civic practice look like, and what are some implications for civic engagement and political participation? The analysis presented here was guided by a pair of questions that emerged over the course of the study: How do young people challenge conventional authority by unconventional albeit sanctioned, means, and what happens when youth use such methods?

The study was conducted in three phases over an 18-month period with a student advisory board in an urban California public school district. Student representatives on the district SAB were elected or appointed from nearly 20 high schools3. Each high school was able to have two representatives. Their schools ranged in size from roughly 100 to 2500 students and included comprehensive, alternative, and continuation high schools. Twenty-one of 27 active representatives consented to participate in the study. Two-thirds of study participants were female, students were between $10^{\text {th }}$ and $12^{\text {th }}$ grades, and they represented the economic and ethnic diversity of the district community 4 .

\section{Participant Observation}

Data collection proceeded in three phases during and 18-month period. Data came from field notes written during participant observation, interviews, and artifacts including drafts of resolutions (policy proposals), meeting minutes, student notes, emails, and documents to support students' learning about the policymaking process. Field notes provided detailed accounts of discussion, debate, and presentations made during SAB meetings. Collected artifacts made changes in young people's work and thinking visible, as when they continued to debate a topic by email or repeatedly revised the text of a formal resolution to the school board. My participant role with the group began when I served as an intern and evolved into a program assistant. One benefit of this role was that the students had decision-making power about whether I could join their team as an intern and researcher. They asked that I convert my field notes to 
minutes that were then reviewed for accuracy during meetings as part of parliamentary procedure. In this way, minutes became a critical artifact for ensuring accuracy and gaining understanding of student perspectives in relation to my perspective as a participant observer. Likewise, the process gave students a look into my observation practices and research interests, which helped us to build rapport over time.

My position as a researcher and participant observer was persistently negotiated. I was initially hired as an intern by the community-based institute (CBI) that was contracted by the district to staff the SAB. I was interviewed by two of the SAB's student representatives and their main staff person. My responsibilities were to attend meetings, take notes, create the minutes, and provide administrative support as needed. Other regular attendees at $\mathrm{SAB}$ meetings included a district liaison to the SAB, typically a Special Assistant to the Superintendent. As time passed, students occasionally invited my participation or point of view on various matters. I collected email communications on which I was copied. In my staff role, I sent out agenda packets and other meeting materials. Otherwise, I was a passive observer email communication without contributing to online discussions. I did play a more active role in event planning and logistics. In higher stakes conversations toward the end of Year 2, I was periodically consulted to offer a perspective on what was at stake, but I did not offer opinions on what students should do.5

Preliminary observations of SAB meetings took place beginning winter of Year 1 . In Year 2, observations continued in public meetings and also included cabinet and subcommittee meetings6 as well as related events. My practice was to type field notes on my laptop during meetings while sitting at the table alongside the students. Students sitting near me often looked over my shoulder to read what I typed, and at times, would say things just to see if I would note them. When I did, the students laughed and expressed understanding that my field notes were as precise an accounting of what was discussed as possible without including interpretation of events. Those moments also helped me note active moments when my presence as a researcher affected the activity and reminded me to attend to my positionality and presence as a factor throughout data collection. When I needed clarification about an interaction at a meeting, I would ask clarifying questions of students in a kind of on-the-spot, informal interview. I collected artifacts throughout. When students produced drafts of their work to discuss or staff members provided resources to organize meeting activities, I archived copies. When the SAB's work came to the attention of local journalists, I gathered news articles and press releases. In addition, I noted their multiple uses of technology throughout the study. At the end of Year 2, I conducted 1-hour semi-structured interviews with 13 representatives from 11 schools, including one representative per school and all but one SAB cabinet member. Interviews were audiotaped, and I also took notes on my laptop during interviews to develop a content log of the conversations. Questions focused on how students assigned meaning to their representative role and to the SAB more generally. Interviews also asked when and how students used available resources for participation, their sense of working with adults, and their ideas about how youth can be part of decision-making processes.

On one hand, while the SAB's practice was intensely focused within its own weekly activities, student representatives consistently expressed their vision for working 
in more integrated ways with the school board. The SAB also interacted with a wide range of community-related groups over time (e.g., the local transit authority, anti-war protestors, food justice activists, youth organizers and activists in other organizations, etc.). A strength of this research design was its ethnographic method the depth of available data on how the group negotiated meaning across a wide variety of circumstances and among people with varying degrees and access and influence in the school district. A key limitation of the design was limited access to adult policy makers, and in turn, the development of their points of view, particularly at the level of the school board and superintendent's office. To address this limitation, I attended to students' regular communication with district liaisons, press communication among adult leaders in the district, school board meeting minutes, and periodic observations of school board meetings. In addition, the SAB's cabinet had a regular meeting with the Superintendent, and their reports about those meetings provided insight into ways in which the SAB's participation was welcomed and also constrained.

\section{Event Analysis}

Over the course of the study, the SAB handled a range of issues including, addressing their own work process, providing advisory feedback, communicating with constituents, and bringing formal resolutions for consideration to the school board. In most cases, the topics they addressed spanned several meetings. In order to analyze the group's trajectories for learning and action, I conducted an event analysis, taking into account the timeline of each of the topics the $S A B$ took up. For the SAB, these conceptual units were identified as old and new business on their meeting agendas, and a variety of artifacts were generated in relation to the events that could be analyzed in terms of origin, framing of the issues over the course of discussion, and actions. Eighteen events were identified in Year 1, and 43 events were identified in Year 2 for a total of 61 events during the period of study. For each event, I identified all points of relevant data: field notes, agendas, minutes, emails, interviews, and artifacts. I then coded and categorized the ways that young people negotiated which topics they would address, how those topics were introduced, and how they would take action by considering who spoke and under what conditions, their language choices in conversation and in the texts they generated, their votes, etc. In addition, I examined their commentary during individual interviews in relation to the collective data set. Finally, I analyzed evidence of effects of their actions, the lack thereof, and interpretations of those effects, as revealed through published media coverage, commentary by students and adults, and meeting agendas and minutes from the SAB and the school board.

For every identified event, I mapped each piece of available evidence that addressed the event: (a) listings in cabinet meeting and regular meeting agendas as well as public notices, (b) student representatives' dialogue detailed in field notes, (c) summaries described in meeting minutes which the students had approved as the official record of their meetings, (d) email threads in which students discussed or debated the events asynchronously, (e) any related artifacts of student work, staff support, communitybased interactions, or media coverage, and (c) interview data where students specifically referenced the event. Initial codes focused on tools, practices, and negotiation of meaning 
within the SAB and on interactions with community and district-related groups and individuals. They were developed based on a combination of conceptual ideas from cultural studies, youth studies, and political sociology literatures as well as themes that student representatives identified or discussed during meetings and interviews and concepts that grounded the research questions. These included representation, identity, production, consumption, regulation, and negotiation (Du Gay, Hall, Janes, Mackay, \& Negus, 1997; Rosaldo, 1994), mobilization and framing (Snow \& Benford, 1988; Snow, Rochford, Worden, \& Benford, 1997). Codes that emerged from discourse and practice among students included voice, participation, respect, authority, representation, and process. For a given event, I began with analysis of field notes and meeting minutes in order to code for evidence of processes and strategies for negotiating meaning that students directly employed. I would then trace the event across the data set in an effort to triangulate negotiations of meaning through selection processes, spoken and written discourse, formalized textual arguments, and public perception as represented through media coverage, press releases, etc. After developing definitions for initial codes and assessing frequency in relation to context, a second round of coding yielded categories of practice and process that revealed ways in which the SAB collectively negotiated and attempted to develop forms of authority: technical, pragmatic, and political framings of their work (see Booker, 2010). These categories were analyzed in concert with student discourse and selected actions (and inactions). Likewise the events, as whole units, were categorized by purpose: (a) process and organization, (b) advisory support, feedback, and participation, (c) constituent communication and convening, and (d) formal resolutions.

\section{Placing the SAB in context: why voice is not enough}

A critical task for SAB representatives was learning to interpret the politics and parameters of the community they were trying to influence. When I encountered the group, they were diligently revising their bylaws. As they refined the bylaws, and struggled to develop a document that the superintendent and board of education would approve, meeting attendance declined significantly. The group's need for a quorum (a simple majority), even to adopt their new bylaws, posed a serious problem. How had they arrived at this crossroads?

Students frequently cited the dismissal of one of their student delegates - one of two SAB members who participated at school board meetings and cast advisory votes - due to improper appointment procedures. His removal-or rather, the superintendent's ability to remove him - shined a spotlight on the SAB's incredibly outdated bylaws. They had not been updated since the 1980s and until they succeeded in getting the school board to adopt an updated version, they were unable to move forward.

The delegate's removal created a strong awareness for SAB members that voice was not an unassailable right. While the dismissal was a technical decision, it is worth noting that the delegate had also been a vocal critic of the superintendent during board meetings. In addition, district staff members that supported the SAB were also dismissed. His removal, then, was correlated with his publicly shared differences of opinion with the superintendent. The SAB was the formal avenue in the district for 
young people to register their opinions about district policies and goals - it was the 'official' voice of the students. The SAB provided four main avenues to express this kind of voice: endorsements, non-binding resolutions, public comments and advisory votes by student delegates during school board meetings. In order to make those statements, the group was responsible to demonstrate that they spoke on behalf of their constituents rather than themselves. Meetings were attended by local journalists and recorded, so public comments could be heard more widely than at the meetings themselves but only if they could sustain their participation rights.

The SAB had become a flashpoint for negotiating what youth voice and participation rights would look like and whether they would be influential or ornamental. Other local youth governance and youth organizing groups were acting as watchdogs to protect student voice in the school district, using their own means of action to exert public pressure on district leaders. A resolution drafted by the city's youth commission - a youth governance board to the local city council-supported a bylaws revision specifically for the purpose of establishing youth influence: "WHEREAS; The [SAB] lacks the power to act on its own and can be prevented from taking any position on an issue, even if the decision was made by majority vote..." This illustrated a broader concern among youth advocates: where is the SAB's power to act established and how is it protected? For this reason, they publicly supported the rewriting of the SAB's bylaws and asked the city council to do the same because as a governance group, they anticipated the necessity of the paperwork. Yet, even with broad public support, the power of access and enforcement was largely in the hands of the superintendent.

$S A B$ representatives began to discern how their group was situated in a wider set of local politics through the dismissal of their delegate and the suspension of their ability to act, pending updated and approved bylaws. This was an important, unfolding process for the students because it marked a moment when they began to actively interrogate their potential authority in a bureaucratically focused way.

\section{Learning how bureaucratic authority works}

Article IV - Representatives, Section II B: All candidates shall receive a mandatory introduction to the [Student Advisory Board], including its bylaws, by the $[\mathrm{SAB}]$ members prior to the election/appointment (Approved SAB Bylaws, February, Year 1).

Rewriting bylaws required $\mathrm{SAB}$ members to detail the purpose of the organization, who could participate and how they would be selected, how a quorum would be counted, what the consequences of absence would be, how meetings would be organized, who would serve on committees, how votes and discussions would be managed, etc. Minutes from seven meetings held over 4 month period showed the group's fatigue and resilience. During that time, their agendas consisted of bylaws work, school reports, retreat planning for new members in anticipation of successfully passed bylaws, and a nutrition resolution that was the only direct student business on the table at the time. But what it lacked in inspiration, it made up for in foreshadowing domains 
of influence. As it turned out, looking closely at the paperwork made the difference between modeling what policy makers do and beginning to participate in the action.

Their work pattern was to discuss goals in a general meeting, send the document to a subcommittee to draft the language, return to share the draft with the large group, submit the draft to the superintendent and the district's legal office for feedback, return to group discussion to address recommended changes, return to subcommittee, and repeat as needed. The task was technical and at times tedious as evidenced by the drop in attendance, students putting their heads down on the table or doing their homework during discussion. In November of Year 1, the SAB held a brainstorm about their purpose:

The themes were as follows: 1) Provide student voice to the Board of Education, 2) A group of students trying to work out problems at school sites, 3) Presenting resolutions to the school board, 4) Helping youth in the city to improve conditions of their lives, 5) Making sure every student voice is heard, 6) Making decisions that are best for the students - not biased, but based on our research about what students want.

The bylaws subcommittee then met separately to negotiate these points into this final text:

Article II - Purpose: The [Student Advisory Board] is a citywide, youth-led organization that is committed to providing a voice for the students of the [district] by representing and presenting the interests of the students to the administrative and policy making bodies of the [district] (SAB Bylaws, Final Approved Version, February Year 1).

Articulating the group's purpose actively guided their decision making about what issues to address and how to address them, and the bylaws were their reference point.

In the meetings that followed, they reviewed the 1982 bylaws and the draft from the previous spring and devoted future agenda time to completing the process with an end of December goal to return to the school board for approval. Having submitted a draft for review, they had received feedback on two articles. The SAB secretary's November notes stated, "at [the] last meeting, we fought alternate," regarding a "strong recommendation" from the district's legal department and superintendent's office that would have resulted in principals appointing one of the two representatives and that representative's alternate. At the end of January, this point of contention was still being addressed. In a 5 to 4 vote, they selected the first of following two options:

Submit solution decided on by $[\mathrm{SAB}]$ members, regardless of recommendation: Jointly appoint alternates with the [SAB] member and their school principal; or Accept the recommendation that elected [SAB] members have elected alternates and appointed [SAB] members have appointed alternates noting the group's disapproval and why (Minutes, January, Year 2). 
The bylaws subcommittee then drafted the joint appointment text and returned to the February meeting where joint appointment received support by a 9 to 2 margin. Although they risked having their bylaws rejected again, they ultimately voted to stick with a joint appointment process that would keep students involved in every aspect of sending representatives to the $\mathrm{SAB}$. The final text of the bylaws addressed this process in painstaking detail:

The representatives and the principal or vice principal shall meet to develop the criteria for alternate selection with guidance and input from the principal. The representatives shall then compile a list of 10 candidates that meet the aforementioned criteria. The principal or vice principal shall then select two alternates from this list. In the rare event that the principal cannot find a suitable candidate from this list, the alternates shall be the $1^{\text {st }}$ and $2^{\text {nd }}$ runners up from the election. If there are no runners up, then the [SAB] representatives will provide another list of 10 candidates that meet the aforementioned criteria... (Approved SAB Bylaws, Article IV, Section II).

This language in their bylaws was consistent with their practice of vigilantly advocating that youth were in charge on the $\mathrm{SAB}$, and adults, including allies, should be disciplined to remain in supporting roles.

Their concern with maintaining youth influence within the SAB was coupled with their commitment to establishing processes that would promote their public reputation as a legitimate, reliable organization. This was evident in how they addressed quorum and voting in their bylaws. Initially, they had proposed a super majority as the standard for establishing quorum as a way to show strong student participation when the SAB took a position. Upon review, the district's legal department had recommended sticking with a simple majority - the parliamentary standard. Their discussion about whether to accept the recommendation focused on the feasibility of achieving a supermajority. Importantly, the SAB secretary's notes suggest how they were negotiating their sense of legitimate action with the superintendent's office. If every school sent its 2 representatives, they could anticipate up to 50 members on the SAB. The debate was whether they would need 34 attendees to take action or 26.

Chris' and Tolan's concerns with reaching their numbers and being able to act quickly were balanced against Milton, Eleanor, and Janel's interest in setting a higher standard. Jack critiqued the impulse to exceed what was an acceptable standard for the school board itself. They had to balance their experience of the superintendent's regulatory moves with their experience of having recently dropped to as low as 9 attendees. Milton referenced one idea they had discussed: removing representatives who no longer attended meetings. Poor attendance made it difficult to establish legitimacy and to act. High attendance with broad representation from schools would counter this problem. In terms of paperwork, that meant establishing rules for attendance and removal, and they did ultimately spell all of this out in their bylaws. But it all hinged on the quorum debate, which boiled down to a single sentence in their final, approved bylaws: "No action may be taken unless a majority of the current [Student Advisory Board] representatives are present." These small maneuvers, 
visible in process rather than final content, helped the SAB representatives establish a nuanced understanding of the possibilities in the paperwork.

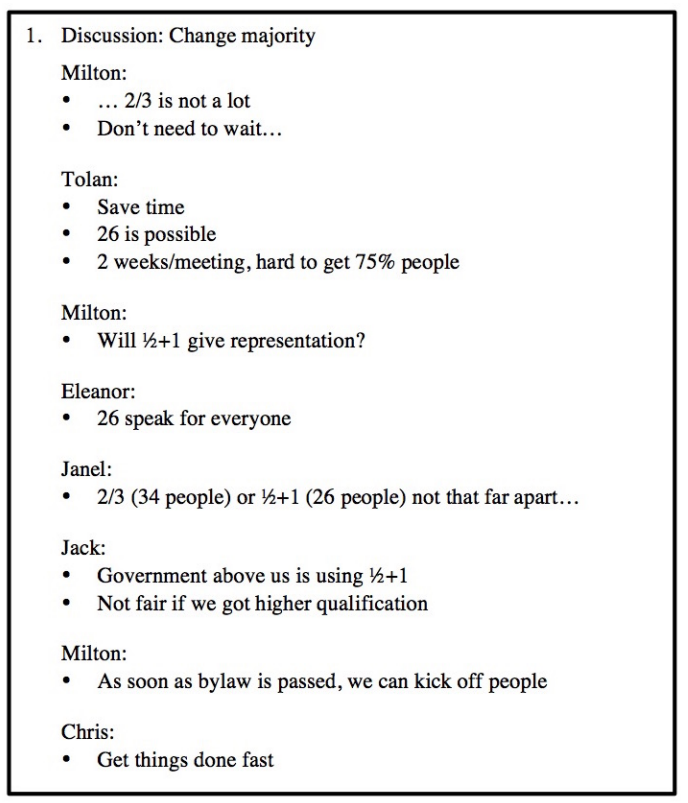

Artifact 1. SAB Secretary Meeting Notes - Discussion of Voting Recommendation

\section{Situating the Rules}

This micro-level focus on the detailed language of the SAB bylaws was paralleled by their quieter and longer-term effort to gain the ability to introduce legislation to the school board. To the students, a key challenge to exercising authority was their conception as an advisory group. They could not introduce their own legislation to the school board. Rather, they had to secure a co-sponsoring board member to get their resolutions considered. Likewise, they did not have a vote on the school board. Instead, their two delegates attended board meetings, sat at the dais, could comment, and would cast the first two advisory votes on actions before the board, ostensibly to inform the school board members of student perspectives before they cast their own votes. This pageantry of influence is convincingly critiqued by critics of such youth boards.

It was evident the $\mathrm{SAB}$ was critical of their advisory status as they pursued the right to directly introduce legislation to the board and to make motions. In the previous year, the school board had adopted a resolution to strengthen student voice that stopped short of authorizing students' power to introduce legislation. Rather, it affirmed the need to provide office space, full access to non-privileged information, and to encourage regular interaction among student delegates and school board members. Their next step was to propose changes to their legislative power, citing the State's education code: 
Section 35012 of the Education Code regarding student delegate motions states: 'The governing board may adopt a resolution authorizing the nonvoting or preferential voting pupil member or members to make motions that may be acted upon by the governing board, except on matters dealing with employer-employee relations pursuant to Chapter 10.7 of Division 4 of Title 1 of the government code' (Draft resolution: Student Initiative, Year 1).

They understood the school board's own contingent authority in these circumstances: the state afforded them the authority to extend this authority to students. Having brought it to the school board, its progress had slowed. During a meeting to strategize about this new resolution, the students tried to discern the resolutions chances of success:

[CBI Staff] said the [district] has asked what the [SAB] wanted to do with the resolution since some changes had been made...[Milton] explained that it was tabled, meaning it was delayed. He said it was a way to either shoot down a resolution without doing it directly or to put it on hold to find more information (Meeting Minutes, Year 1).

It was clear that the students did not know how much support there was for expanding the boundaries of youth participation. In addition, their task was bureaucratically complex and indirect. They were drafting a non-binding resolution that invoked authority granted to school boards via state law in hopes that their particular school board would co-sponsor the legislation, adopt it, and change the rules to allow student delegates to make motions. It was a question that had to be explored patiently, over the course of a series of actions along with other activities.

The combination of rewriting bylaws and methodically seeking expanded participation put the SAB in dialogue with tools governing authority in this kind of public policy making: bylaws, parliamentary procedure, board of education policies and state laws like the government and education codes.

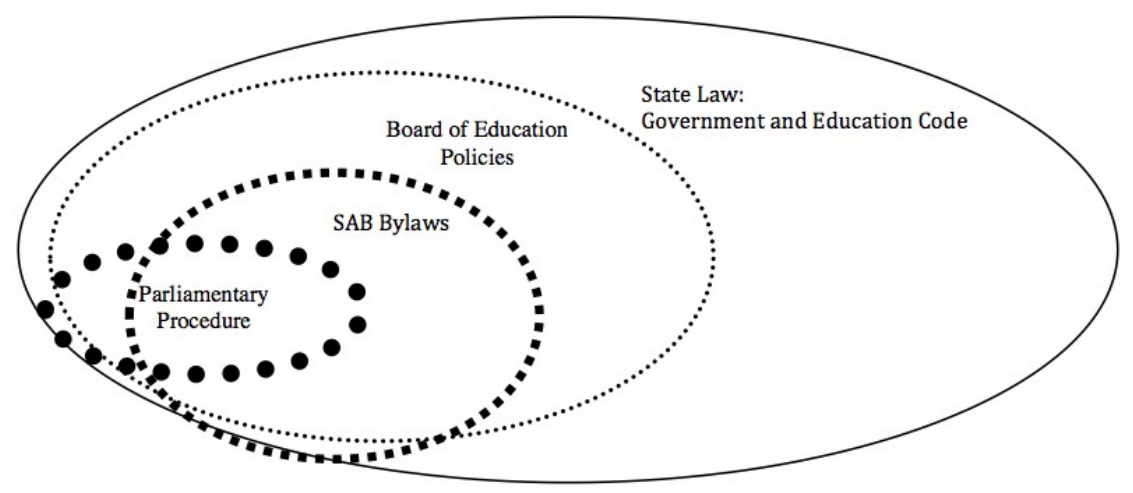

Figure 1. Governing rules and documents 
These systems for governance are what created space for youth to establish influence through contingent authority. The SAB developed their technical understanding of this formalized paperwork and its hierarchy of relationships, shown in Figure 1, through a series of these types of tasks. Of the 61 events analyzed during years 1 and 2 of the study, 25 of them engaged the SAB in the development and exercise of technical knowledge, and 16 of them directly invoked their paperwork. By the end of year 2, after having re-established their role as an official voice for youth in the district, they headed for another public clash with the superintendent. I now examine how the SAB put their paperwork in practice to wield contingent authority.

\section{Youth Exercising Contingent Authority: Publicly Invoking Paperwork}

While the paperwork established parameters for student participation in decisionmaking in board meetings, their authority was established and wielded in public. Young people typically have to build a reputation for competence as a pre-emptive strategy for affirming their participation rights. It is an unevenly applied expectation (Bessant 2004) that has bearing on the public performance of authority.

Once they succeeded in passing their bylaws, the SAB made several moves to establish their competence and legitimacy as representatives. Between February of Year 1 and May of Year 2 they held elections, re-established representation from each eligible school, established regular meetings with the superintendent, hosted 2 student summits for several hundred middle and high school students with the superintendent's sponsorship, provided endorsements to measures from other local groups', surveyed students to prioritize their actions, commented on official documents like the memorandum of understanding governing police officers on school campuses, and drafted twelve non-binding resolutions. By the time they joined a heated public debate in June of Year 2, they had established a process that adhered to standards for public meetings: following state sunshine laws that required a 72-hour notice to the public of meeting agendas and upcoming votes, using parliamentary procedure to run meetings, and returning regularly to their bylaws to interpret and negotiate their rules.

During that same period, the district faced budget cuts and declining enrollments, which led to school closures. The climate of cuts led to a fierce public debate about the superintendent's contract, after the school board held a private meeting in which they approved increased compensation and a severance package, should she retire before the end of her contract. In addition, the teacher's union was fighting the superintendent's signature school reform program because it involved making teachers, staff, and administrators of struggling schools reapply for their jobs. This process, called reconstitution, made it possible to change over the leadership and staff of a school in short order.

During a closing panel of their second annual student summit, Shannon, an SAB representative, revealed that they had been considering these issues and planned to register a formal student perspective on each issue. By late May, they had drafted two resolutions and prepared them for a first reading, largely by meeting and negotiating in private: "I remember long chats debating stuff, like the superintendent's raise with four or five people in a chat. There were pretty much two sides. We had things we all could agree on, but different opinions about how to do it" (Interview, Vince, Year 2). 
Likewise, during our interview, Shannon recalled, "there was the one with [CBI staff] and you and [youth commissioner] and like, [senior CBI staff] wasn't invited...But there were meetings with just students where no one else was invited, like no staff were" (Interview, Shannon, Year 2). The "secret meetings," as several students dubbed them, indicated that the students rightly anticipated a backlash.

\section{Directing Paperwork \& Pageantry to Claim Contingent Authority}

Faced with the challenge of defending their right-as students - to address a contentious public issue, paperwork and technical practice became critical. The demands of authority required mastery of a complex body of tools, including conventions and practices encoded in paperwork. By the time they were introducing resolutions calling on the superintendent to renegotiate her contract and pushing back on reconstitution, the SAB had learned how to read and write resolutions - the formal text for expressing an opinion or developing legislation. That included practices for negotiating and revising their content, moving them through a process from initial introduction, discussion, through committees, and back to the floor for a vote, making their actions legal and official. For these particular resolutions, each of these moves was met with swift resistance and attempts to discredit, postpone, and cancel the SAB's meeting. A key difference between this instance and the dismissal of the student delegate that led to months of bylaws revision was the SAB's increasingly sophisticated understanding of the paperwork.

Three SAB moves illustrate how students came to understand bureaucratic authority and how they might maneuver within it. The first involved following state laws while bringing their resolutions to a public vote. The second was an indirect response to attempts to stifle their efforts by reducing quorum. The third was a direct challenge to the superintendent's authority, issued through their interpretation of how the hierarchy of rules worked.

Having drafted the resolutions and gotten fellow representatives to sign on in support, they scheduled them for a first reading at the second-to-last meeting of the year. They posted a notice of their agenda in the front window of the district office 72 hours in advance of their meeting - as was required by state law. The agenda for their 90-minute meeting was set by the SAB cabinet, as was their custom. It included 5 minutes for public comment, 20 minutes for delegate and committee reports, 20 minutes for second readings of 3 other resolutions, 5 minutes for first readings of the 2 contentious resolutions, and 30 minutes to report on the results of the recently held student summit. Modeling school board practice, once representatives provided the content, the staff distributed a packet with the agenda and resolution drafts. Perhaps predictably, they ran short of time. Three members of the teachers union attended the meeting and spoke during public comment, explaining the history of reconstitution from 1983 forward, challenging its effectiveness as a reform method, and speaking of its detrimental effects on teachers and school communities. Field notes from the meeting discussion illustrate the SAB's approach to decision-making: 
[Union representative explained union position opposing reconstitution]: ... When a teacher gets a job, across the state, the principal has total discretion for the first two years to dismiss a teacher. They will be evaluating the teacher during that time, and hopefully, providing valuable feedback. After two years, if given a satisfactory or highly satisfactory rating, they are given tenure, which means the contract must be maintained through due process...The teachers being reconstituted are teachers who have been evaluated, and there is nothing about their evaluations that is contributing to this reconstitution... [Rep. Calli] asked who decides which teachers get reconstituted. [Union President] explained that a whole school is targeted, and then teachers may reapply. He said, as with any interview process, there is a subjective nature to it....[Rep. Manny] asked about "reform with respect." Many representatives responded. [Rep. Marie] asked the public guests if there is anything positive about reconstituting a school? [Union President] said from the point of view of parents, teachers, and students, the answer was probably not. For principals, there probably was an advantage in their eyes to picking their own staff.

With an explanation of the perils of reconstitution before them, some SAB representatives were ready to vote, while others wanted an opportunity to hear alternative perspectives before deciding. A thoughtful debate about how to proceed, and whether to declare "emergency status" ensued. Consider the process commitments expressed by both students and staff and interpretations considered in the following excerpt:

[Rep. Gerardo] encouraged people to vote yes. [SAB Chair, Rep. Eliza] reminded the group that this was a first reading. [Student Delegate, resolution author] moved to declare emergency status for this resolution. [Rep. Shannon] seconded the motion (among many others). [CBI Staff] added that one side of the issue has been presented tonight, and that the other side has not been presented. [Rep. Shannon] asked if there are particular schools up for reconstitution besides [Reform Program Schools]. [Union President] said the superintendent designated [3 schools this year]. [Seven more] were proposed for the second year, but two of those schools were closed, leaving five... After more debate, [CBI Staff /former SAB member] asked what emergency status is - "It is not defined."...[Student Delegate] said it was an emergency because... everyone here has a clear idea about what reconstitution is about and what it does, and it impacts so many people, and it should be addressed as soon as possible. [Rep. Eliza], as chair, added that the group should consider seriously, what counts as an "emergency," adding representatives should go to their schools to find out constituents' opinions.

Field notes from the discussion give a sense of how student representatives were actively negotiating their process, keeping their knowledge of the rules in their paperwork in mind while adapting to the circumstances. Generally, when following parliamentary procedure, first readings introduced the resolution, and set up the opportunity to decide whether to proceed and to send to committee for development. In other words, a first 
reading on an agenda item implies a vote will not be taken at that meeting. The SAB typically followed this procedure and did not take votes until second or subsequent readings. The distinction here was that both resolutions addressed topics that were being hotly debated in the local community as the academic year neared its end. The students wanted to go on record before summer began and people became unavailable to meet as well as before public attention turned to other topics. With only one remaining full group meeting before the school year ended, they were pressed for time.

Between the last two meetings of the year, members of the SAB cabinet met with the superintendent and then on their own to set the final agenda. Notes from their meeting with the superintendent, which I did not attend, indicated that they were resolving their differences regarding the contract and reconstitution resolutions:

[The superintendent] was hurt that the [SAB] did not want or was not sure about her salary. She said she was glad to see the students discuss it with her and to see that some students had taken their names off of the resolution ([SAB District Liaison Staff] mentioned that 5 students had taken their names off of it). [Rep. Eliza] added that students made their own decisions about taking their names off the resolution and were not forced by any adults.

Two students gave interviews to a local reporter that suggested a more tense situation, stating that staff members had pushed them to remove their names from the resolutions. One student kept her name on while another conceded to the pressure, asserting, 'The only reason people aren't supporting this is because they're afraid about not having a voice. So the stifling - it's already happening.' The students reported their efforts had been met with swift resistance from school administrators as well, with some high school seniors reporting threats to their ability to graduate if they continued.

As a participant observer who witnessed the strain both during student meetings and during staff meetings, I can attest to the high stress of the circumstances (see Booker, 2016). Even the detailed minutes, which I converted from my field notes at the SAB's request, came under scrutiny by a senior CBI staff leader. My initial 8-page draft of the minutes for the final scheduled meeting of the year, that included summaries of each speaker's comments, was edited down to a 3.5-page summary. The final posted agenda for that meeting did not include second readings of the resolutions. Instead, it noted 15 minutes for a presentation on school reconstitution. However, 18 members of the public showed up for the meeting, including some high school students, the district's general legal counsel, an attorney with a firm planning to bring a lawsuit against the district regarding the contract dispute that would ultimately be brought on behalf of one of the student delegates, local youth advocates, and the return of several teachers' union representatives. The meeting was also attended by the aforementioned CBI senior staff member, who had not attended a meeting since the start of the year until the cabinet meeting in the preceding week. The usual CBI staff and the liaison from the superintendent's office also attended. Right away, adults with an interest in these issues posed questions about whether the SAB should vote on their resolutions. I include longer meeting excerpts here to provide a more textured sense of what was required to persist in exercising contingent authority: 
[Rep. Eliza] invited members of the public to [speak]. [Local attorney] wanted to challenge the salary increase received by the superintendent as unlawful. He said he was upset and confused about why the resolution was not on the agenda and added he was here to answer questions and to represent the other side. [Rep. Eliza] explained the [SAB] process for addressing resolutions was to bring them to the council for $1^{\text {st }}$ reading and then to send them to committee. Committees can table a resolution while they work on getting more information about it...[Social worker/student advocate] said the [SAB] is a very important body and that it is student government, and no one has the power to take it away. He was upset the item regarding the superintendent's salary was not on the agenda adding the students should not feel intimidated by anybody, especially adults...they have an enormous responsibility to the students they represent. [Bus driver] said the mayor cut his own salary and asked others making over $\$ 100,000$ to voluntarily cut $10 \%$ of their own salaries, and the youth have to serve as the superintendent's conscience. He added the superintendent should be at the meeting discussing this. [Law school student] said the salary increase was egregious and illegal, that the superintendent did not follow the procedure at the regular board meeting, and that it was unfortunate that the group would be unable to discuss it at this meeting. [High school senior] was present to support students and hear what they had to say...[District's General Counsel] who represents the school board and protects the district, said it was true that two-thirds of a governing body could vote to place an item on the agenda. In this case, the Brown Act rules may still apply. [He responded to the law student, stating]...in terms of the district superintendent, the law clearly stated that legally, the process was sound, though some felt it was wrong. He wanted the [SAB] to know the issue may be taken up in litigation, recommended the students avoid the danger of being involved in an issue that might result in a lawsuit and that students let the lawyers handle the issue...

Adults brought their own agendas to the meeting, and for some time, they continued the ongoing debate about the superintendent's contract. Finally, SAB representatives stepped in to return the conversation to whether or not to vote on the resolutions at this meeting.

[Student Delegate] moved to vote on both resolutions at this meeting. [Rep. Manny] seconded the motion. [Student Delegate] said the cabinet did not follow correct procedure and called to the question to put the resolutions on this meeting's agenda. [CBI Staff] reminded the group that even if parliamentary procedure was properly followed, these items had not been properly noticed. [Rep. Manny] said discussion was being rushed. [Rep. Vince] said the group was pressured because a lot of members of the public were present. [Rep. Shannon] said the [SAB] representatives had been responsible for going back to their [school site teams] to be prepared at this meeting. [Senior CBI Staff] spoke about the cabinet meeting [the previous week]. He said the 
group had followed a process, and voting tonight would violate it. He then cautioned that any person present to pressure the students not to follow their process should be ashamed. [Rep. Shannon] responded, saying she thought the cabinet meeting was not properly noticed, so that was not proper process either. She said [Senior CBI Staff] pressured students in one direction and this was also something to be ashamed of. [Rep. Eliza] requested the group avoid personal attacks and focus on the issue at hand. [Rep. Kristina] said the group should vote. [Rep. Eleanor] reminded the group that someone had suggested calling an extra meeting.

Amidst a great deal of pressure and public scrutiny, the SAB worked hard to focus on representing students, follow the law, the bylaws, and parliamentary procedure. By the end of the meeting, they had earned the respect of those present: "Members of the public complimented the SAB for their efforts to conduct a professional meeting, and the district's general counsel complimented them on 'navigating a difficult meeting very well'" (Field note, June, Year 2).

Ultimately, to comply with the law to give 72 hours public notice of the agenda, the $\mathrm{SAB}$ voted to schedule a follow up meeting that would occur just after the school year had ended. The superintendent made a surprising counter-move by immediately posting a notice to postpone the meeting, stating she would be out of town and unable to attend7. In addition, to counter the SAB's media advocacy, the district's public relations office drafted a 30-page press release suggesting the resolutions had been written by adults and the students had been co-opted. These attempts to discredit, limit what legal actions could be taken, postpone the SAB's meetings, and pressure students to remove their names from support of the resolutions tested their authority. Unlike the moment two years prior, when their student delegate was removed from his post, this time, they were able to respond flexibly. The SAB anticipated the major hurdle in postponing their vote until school ended would be reaching quorum. In response, four students resigned by email in an effort to reduce the number needed to act. Milton replied to challenge this strategy:

But I kind of wanted to say that I don't think it is our place to encourage members to resign. I mean quorum was established for a reason: that we would have at least a MINIMAL amount of all [schools in the district] represented when we make decisions, so when we lower quorum, we are lowering membership represented, which is the strength of our voice..." (Email, Year 2).

Ultimately, they abandoned the quorum reduction strategy and instead checked the rules to see if they had the authority to proceed. Having determined the paperwork would back them up, from bylaws to education code, Eliza wrote to the superintendent in defense of their decision:

"We believe it is important to have this vote. In accordance with the Brown Act we could not legally vote on these resolutions Monday...because we did not notice it 72 hours in advance, hence the meeting being called this Monday. 
We cannot postpone the meeting, nor does anything say you have the legal right to do so. We have checked with lawyers on this matter, to make sure that we are not over stepping ou[r] bounds in keep[ing] the meeting as is, as well as parliamentary procedures. Everything I have read and everyone I have talked to has stated the same thing: (1) that the only people with the power to [cancel] or postpone the meetings are the members, and (2) that it says [nowhere] that the superintendent, nor any other staff, has the power to postpone the meetings.... Though we would like you to attend the meeting, it is unnecessary seeing [as] we are talking for the students. We speak for them, not for the adult[s] of the district" (Email to superintendent, staff, and SAB cabinet members, Year 2).

When the day of the meeting arrived, there was high attendance including members of the press, the teachers' union, students from district schools, CBI staff including their executive director for the first time that year, and several active opponents of the superintendent's recent contract renewal or school reform policy. As the meeting got underway, several adults argued over the legality of the meeting and became concerned with the symbolic role of the podium in the boardroom used for public comments during school board meetings. As some tried to have the podium removed as a signal that the meeting was not legal or official, others argued to keep the podium in place. The students reminded everyone that all they needed to continue was a quorum. They took a unanimous vote to hold the meeting, heard public comment on each resolution, made an amendment to one of the resolutions, and took their votes: 14-0-1 in favor of the contract resolution, 13-0-1 in favor of the resolution opposing the school reform program (one representative had to leave early), and they voted on two other resolutions on the agenda.

It is necessary to remember that for all of this effort, the SAB's actions were not binding in any way and served only an advisory purpose. That said, it would be a mistake to conclude that this meant the SAB lacked authority. A more accurate conclusion is that they exercised contingent authority. They remained subordinate to powerful-or elite-adult decision makers in terms of voting and enforcement power. Yet, within their domain of practice, they began to disrupt the calibration of politics determining the limits of who participates.

There was significant fallout. At the close of the year, the CBI cancelled its contract with the district in protest of the superintendent's actions, the full-time staff person at the institute responsible for supporting the SAB then resigned her position in protest of the decision to cancel the contract. Shortly thereafter, the senior CBI leader also resigned. At the start of the following academic year, the superintendent announced she would be leaving the district at the end of the year. Her departure cannot be said to be the result of student pressure. In a large city and unified school district, it is common for superintendents to navigate a great deal of political pressure. However, it can be said that the students' challenges contributed to the end of her tenure with the district. Their real authority, however, was in maintaining their legitimacy, resisting the superintendent's perceived power of enforcement, maintaining the possibility for influential student participation to emerge in the district, 
holding their meeting, and rendering an official publicly acknowledged opinion on behalf of students in the face of intense pressure to regulate and even silence them.

\section{Discussion}

This article contributes to literatures on youth studies and public participation, and more broadly, sociology of education. I have described how having command of the levels of paperwork in a bureaucratic system became a powerful tool for young people to use in contentious conditions, particularly those who were often underestimated and whose actions or intentions were not always legible to existing authority. They ultimately crafted a political tool to ensure and expand participation. Attempts to wield authority surfaced hidden conventions about who could and could not participate, how, when, and under what conditions. Young people, in roles as students and advisory representatives - having been granted a position in 'modern officialdom' (Weber, 1978)-engaged in practices leading them to integrate technical practice, purposeful action, and public performance. In turn, they exercised contingent authority in processes conceived to keep them on an age-segregated sideline. The authority available to students was contingent and constrained, but that did not diminish its strength within carefully defined contexts.

These findings have three main implications. First, while youth advisory councils traditionally produce a form of exclusion that implicitly justifies itself on developmental grounds-framing youth as immature and underprepared for public participationthese councils concurrently provide parameters within which contingent authority can be established. Second, rather than being either non-participatory or participatory, either tokenizing or influential, youth advisory councils can present a site that reveals how these circumstances intertwine and can be negotiated or contested. Third, there is power in the paperwork, but accessing it requires a sustained and public practice. I will elaborate each of these implications and propose next phases of inquiry into limits and potential for youth to exercise authority given developmental, social, political and bureaucratic framings of public participation.

\section{Youth participation as a developmental process}

Youth advisory councils are inscribed with developmental features that are monitored by their founding institution or organization. While they establish sites for potential participation (Fleming, 2013), they have been effectively critiqued for reproducing forms of non-participation (Taft \& Gordon, 2013). Such councils also offer sites for learning technical knowledge that is considered developmentally appropriate, while legally restricting the related participatory practices. This is accomplished by eliminating voting privileges and the ability to introduce legislation. In this way, youth advisory councils make visible ways that institutional restrictions reproduce non-participation and performance without authority.

Interestingly, in the case of the district $\mathrm{SAB}$, opportunities to learn, both planned and unplanned, were organized around young people's attempts to influence the district's decision-making process. Young people did, in fact, learn quite a lot when handed the 
momentum-depleting task of re-writing bylaws. Adults, when facing a direct challenge to their authority, did not always perceive it as learning. The superintendent described it as politicizing and co-opting of young people in her 30-page press release. It may be reasonable to conclude that adults who held a primarily developmental view of students did not recognize how far young people could get with their technical knowledge, given the diminished form of authority available to them.

I have argued that a next phase of study for scholars concerned with youth participation is to articulate and examine forms of authority. Available forms of authority can indicate how young people and their allies might navigate the complexities of participation in particular contexts. Age-based exclusion operates on a developmental logic. Developmental pathways toward expanded participation are similarly conceived. When disruption of young people's access to authority is made legitimate, the stability of the distribution of adult authority is affirmed. In other words, non-participation and a lack of authority are desirable when the stability of bureaucratic distribution of authority is prioritized. This runs counter to notions of developing toward full participation. This case suggests that mechanisms of age-based exclusion, made legitimate through state and institutional means, can also contain a counter-mechanism in the form of contingent authority. Young people may claim this bureaucratic form of authority and use it to challenge developmental justifications for exclusion. This opens an area of inquiry where youth development and civic engagement are studied as emergent participatory processes.

\section{Youth participation as a social and political process}

Social and political understandings of youth participation inform the conditions in which authority is accessed. The literatures that frame participation in these terms have been concerned with youth participation as an indicator of the degree to which a political system is humane or democratic (Bessant, 2004; Camino \& Zeldin, 2002; Hart, 1992; Matthews \& Limb; 2003), as a gauge of efficacy between social and political organization in a society and its relative stability (Bennett 2008; Fleming, 2013; Smith et al., 2005), and as a means for organizing for social change (Camino \& Zeldin, 2002; Ginwright et al., 2006; Kirshner, 2015).

The district SAB worked hard to express forms of citizenship that mapped well to human rights, socially constructive, and dutiful modes of citizenship. They tended to reflect a human rights version of youth participation - a rejection of non-participation as unjust. At the same time, they embraced traditional versions of civic engagement by modeling careful, dutiful practice. As they worked to mobilize a constituency, they grappled with concerns over apathy and diminished interest. Simultaneously, they sought authority to expand opportunities for a fuller range of participation for young people in their school district. Where the expansion of authority was involved, this was met with resistance and attempts to regulate them. It is evident that the district $\mathrm{SAB}$ recognized and was willing to work within existing limitations while pushing for inscription into power relations of the school district and, by association, the state. In these ways, they expressed concurrently multiple framings of citizenship, always with attention to where they might establish or expand authority. Bureaucratic 
structures of participation define some forms of authority that youth can leverage and this can inform inquiry where human rights, youth organizing and activism are studied as indicators of citizenship and change, particularly where access to authority is challenged by the persistence of delayed participation.

\section{Contingent authority as an indicator of youth participation in a bureaucratic process}

Mukerji (2011) described what contingent authority could do within state administration in $17^{\text {th }}$ century France: "the effect was to reduce the relative autonomy of nobles as public officials and landholders, but without challenging nobility as the fundamental principle of power." Over 300 years later, what we see here is similar. Even with the establishment of contingent authority, adult authority over young people remains a fundamental principle of power. But the relative autonomy of powerful adults can be reduced. The relative authority of young people can be increased. Even establishing that much can be a heavily contested effort.

Paperwork provided a way to claim contingent authority under conditions that justified age-segregation, but wielding it demanded more than knowledge. Rather, young people invoked paperwork purposefully, publicly, and repeatedly. Young people asked relatively direct, simple questions that have been asked by young people on various youth councils for generations: Can we get a real vote? Can we introduce legislation? Writing bylaws under duress brought them into contact with layers of policy that organized technical rules in relation to one another. It is notable that new members who joined the SAB could then be apprenticed by their peers into the technical practices necessary to wield contingent authority without having gone through the direct exercise of writing bylaws. The result was the opening of a small space with some contingent authority written in, enough to establish some deeplyrooted, if limited, influence.

Yet, limits remain to temper enthusiasm. The power of enforcement is distinct from general tenets governing access to participation. The contingent authority of powerful adults-specifically the superintendent and elected school board members - included assigning resources, closing schools, making hiring and firing decisions, allocating funds, etc. Students lacked this power of enforcement. State organization of power, as administered by adults, was not jeopardized. This is consistent with Mukerji's finding that the fundamental premise of power remained undisturbed. What the SAB made visible was how students wielded contingent authority in public discourse when they lacked such power. In addition, learning to wield authority in the direction of a group's goals is distinct from discovering access to a form of authority. This extends well beyond youth advisory councils to legal, economic, and social forms of organization. If groups like, but not limited to, advisory youth councils become aware of how they can establish contingent authority, and begin to wield it purposefully and effectively, modern liberal democratic notions of participation may face new claims on authority that emerge from patterns that have typically legitimized their exclusion. 


\section{References}

Booker, A. (2010). Framing youth civic participation: Technical, pragmatic, and political learning. In L. Lin, H. Varenne, \& E. W. Gordon (Eds.), Educating comprehensively: Varieties of educational experiences (pp. 209-231). Lewiston, NY: Edwin Mellen Press.

Booker, A. (2016). Ethical commitments in community-based research with youth. Mind, Culture, and Activity: An International Journal, 23(1), 15-27.

Bennett, W. L. (2008). Changing citizenship in the digital age. In W. L. Bennett (Ed.), Civic Life Online: Learning How Digital Media Can Engage Youth (pp.1-24). MacArthur Foundation Series on Digital Media and Learning. Cambridge: The MIT Press.

Bessant, J. (2004). Mixed messages: Youth participation and democratic practice. Australian Journal of Political Science, 39(2), 397-404.

Camino, L., \& Zeldin, S. (2002). From periphery to center: Pathways for youth civic engagement in the day-to-day life of communities. Applied Developmental Science, 6(4), 213-220.

Du Gay, P. , Hall, S., Janes, L., Mackay, H., \& Negus, K. (1997). Doing cultural studies: The story of the Sony Walkman. London: SAGE Publications.

Fleming, J. (2013). Young people's participation - Where next?. Children E Society, 27(6), 484-495.

Ginwright, S., Noguera, P., \& Cammarota, J (Eds.). (2006). Beyond resistance: Youth activism and community change. New York: Routledge.

Hart, R. A. (1992). Children's participation: From tokenism to citizenship. New York: UNICEF.

Kahne, J., \& Middaugh, E. (2008). High quality civics education: What is it and who gets it?. Social Education, 72(1), 34-39.

Kirshner, B. (2015). Youth activism in an era of education inequality. New York: NYU Press.

Matthews, H., Limb, M., \& Taylor, M. (1998). Young people's participation and representation in society. Geoforum, 30(2), 135-144.

Matthews, H., \& Limb, M. (2003). Another white elephant? Youth councils as democratic structures. Space and Polity, 7(2), 173-192.

Mukerji, C. (2011). Jurisdiction, inscription, and state formation: Administrative modernism and knowledge regimes. Theory and Society, 40(3), 223-245.

National Center for Education Statistics. (2011). The nation's report card: Civics 2010 (NCES 2011-466). Washington, DC: Institute of Education Sciences, U.S. Dept. of Education.

Rancière, J. (2010). Dissensus: On politics and aesthetics. London: Continuum.

Rosaldo, R. (1994). Cultural citizenship and educational democracy. Cultural Anthropology, 9(3), 402-411.

Smith, N., Lister, R., Middleton, S., \& Cox, L. (2005). Young people as real citizens: Towards and inclusionary understanding of citizenship. Journal of Youth Studies, $8(4), 425-443$.

Snow, D. A., \& Benford, R. D. (1988). Ideology, frame resonance, and participant mobilization. International Social Movement Research, 1, 197-217.

Snow, D. A., Rochford, Jr., E. B., Worden, S. K., \& Benford, R. D. (1997). Frame alignment processes, micromobilization, and movement participation. In D. McAdam \& D. A. Snow (Eds.), Social movements: Readings on their emergence, mobilization, and dynamics (pp. 235-251). Los Angeles: Roxbury Publishing Company. 
Soep, E. (2014). Participatory politics: Next generation tactics to remake public spheres. MacArthur Foundation Reports on Digital Media and Learning. Cambridge: The MIT Press.

Taft, J. K., \& Gordon, H. R. (2013). Youth activists, youth councils, and constrained democracy. Education, Citizenship and Social Justice, 8(1), 87-100.

Veerman, P. E. (1992). The rights of the child and the changing image of childhood. The Netherlands: Martinus Nijhoff Publishers.

Weber, M. (1978). Economy and society: An outline of interpretive sociology. Berkeley: UC Press.

Westheimer, J., \& Kahne, J. (2004). What kind of citizen? The politics of educating for democracy. American Educational Research Journal, 41(2), 237-269.

\section{Notes}

1 Hart (1992) rightly cautioned that participation is not automatically positive and must be understood as a process of co-construction promoting the good of the community-itself a potentially contested notion.

2 SAB elections were distinct from the councils described: each school sent an elected representative and appointed representative who had previously been chosen by peers, a point of careful consideration.

3 All names are pseudonyms.

4 At the time of study the district's website listed this demographic information: student population was roughly 9\% White, 13\% African American, 22\% Latin@, 32\% Chinese, and 24\% identified as Filipino, Japanese, Korean, Native American, and other non-White. Fifty languages were spoken. The attendance rate was $95 \%$ with $82 \%$ of seniors graduating. $55 \%$ of students were eligible for free and reduced lunch.

5 For a more detailed discussion of my role as a participant observer see Booker (2016). When reporting ethnographic data, I have distinguished researcher and student interpretations by sharing detailed field notes and minutes that preserve the tenor of students' interactions.

6 Each year, the SAB elected a group of students to its cabinet who served as the group's organizing leaders. The full group of SAB representatives met biweekly. In the alternate weeks, cabinet members met to set the agendas and plan ahead for upcoming issues and activities. Students formed subcommittees to address specific, shorter term issues or to plan events for the broader student population, and those meetings were held at students' convenience. I attended regular meetings, cabinet meetings, and when possible, subcommittee meetings.

7 The SAB alternatively suggested she send a representative, allow a cabinet member to interview her and relay her perspective, or adjust her travel plans.

Fecha de recepción: 19 de noviembre de 2016

Fecha de revisión: 19 de noviembre de 2016

Fecha de aceptación: 10 de marzo de 2017 